\title{
GDP Growth and Indirect Taxation in Bangladesh: Related Issues, Consequences and Expectation
}

\author{
Aoulad Hosen \\ Department of Economics, National University, Gazipur, Bangladesh \\ Email address: \\ drhosen71@gmail.com,olee018@yahoo.com \\ To cite this article: \\ Aoulad Hosen. GDP Growth and Indirect Taxation in Bangladesh: Related Issues, Consequences and Expectation. International Journal of \\ Business and Economics Research. Vol. 8, No. 5, 2019, pp. 286-296. doi: 10.11648/j.ijber.20190805.15
}

Received: July 10, 2019; Accepted: August 6, 2019; Published: August 20, 2019

\begin{abstract}
This is an empirical study that takes GDP growth and indirect tax in Bangladesh as its cynosure. It examines the relationship between the growth rate of Gross Domestic Product (GDP) and the indirect-tax for the policy issues regarding long-term macroeconomic stability as well as economic development of Bangladesh. This paper focuses on the impact of indirect taxation on GDP and demonstrates the influence that taxation has on the tax paying individual and business firms irrespective of economic scale. To analyze the relationship between GDP and indirect tax, this research incorporated econometric models for time series data of Bangladesh over a period of 43 years. The results show, if the Government in the long run increases the collection of indirect tax revenue by one percent (USD 167.511 million) then the GDP will decrease to a 0.96 percent (USD 2,572 million). The study concludes that the stability of economic growth can be achieved through a reformed tax policy on the basis of the country's socioeconomic strength and the canons of taxation.
\end{abstract}

Keywords: GDP, Economic Growth, Econometric Methods, Indirect Tax, Social Justice and Tax Reform

\section{Introduction}

The revenue earning of a government is mainly based on the policy of taxation of that nation. Taxation is the primary source of government's revenue earning. Imposing tax is an intricate matter for covering government revenue earnings and ensuring steady tax policy. Government policy makers require to be prudent and discreet while imposing tax on individuals and firms by ensuring equity, fairness and social justice. For the sake of economic assiduity, fiscal policy, including taxation, acts as a vital instrument of revenue earnings all over the world. The primary purpose of taxes is to raise revenue for public spending, what is equally important is the role of redistribution of this income in order to reduce inequality. Taxes and social transfers can have an immediate effect on income distribution, while social expenditure on education, health, and infrastructure investment tends to have a more long-run impact. Among lots of instruments of taxation, choice of instruments of taxation has become a key factor. It would have been better if the government had considered the possible impacts of using tax instruments in order to reduce income inequality in Bangladesh.

Taxation serves various development purposes to which Bangladesh is no exception as it also depends on tax for raising its development budget especially in the area of infrastructure and human development. Revenue collection tools of fiscal policy in Bangladesh are mainly based on tax revenue and non tax revenue. Although the revenue earnings from both sources of taxes are gradually increasing from $2010 / 11$ to $2017 / 18$ but the share of revenue income of both tax entities of GDP is near similar in the time frame (Table 1). In other words, government dependency on revenue collection irrespective of both entities remains the same.

Table 1. Revenue Receipts (In Crore Tk.).

\begin{tabular}{|c|c|c|c|c|c|c|c|c|}
\hline Particulars & 2010-11 & 2011-12 & 2012-13 & 2013-14 & 2014-15 & 2015-16 & 2016-17 & 2017-18 \\
\hline Total Revenue & 95187 & 117033 & 139670 & 156671 & 163371 & 177399 & 218500 & 259454 \\
\hline Tax Revenue & 79052 & 94754 & 116824 & 130178 & 140676 & 155399 & 192261 & 232202 \\
\hline Non-tax Revenue & 16135 & 22279 & 22846 & 26493 & 22695 & 22000 & 26239 & 27252 \\
\hline
\end{tabular}




\begin{tabular}{lllllllll}
\hline Particulars & $\mathbf{2 0 1 0 - 1 1}$ & $\mathbf{2 0 1 1 - 1 2}$ & $\mathbf{2 0 1 2 - 1 3}$ & $\mathbf{2 0 1 3 - 1 4}$ & $\mathbf{2 0 1 4 - 1 5}$ & $\mathbf{2 0 1 5 - 1 6}$ & $\mathbf{2 0 1 6 - 1 7}$ & $\mathbf{2 0 1 7 - 1 8}$ \\
\hline As percent of GDP & & & & & & & & \\
Total Revenue & 10.39 & 10.88 & 11.65 & 11.66 & 10.78 & 10.24 & 11.68 & 12.18 \\
Tax Revenue & 8.63 & 9.12 & 9.74 & 9.69 & 9.28 & 8.97 & 10.28 & 10.90 \\
Non-tax Revenue & 1.76 & 1.76 & 1.91 & 1.97 & 1.50 & 1.27 & 1.40 & 1.28 \\
\hline
\end{tabular}

Source: Bangladesh Economic Review’2018, Ch. 4 P. 43

The lion share (more than 80 percent) of revenue comes from tax revenue which consists of mainly two types of taxes such as direct tax (for more, please see the Appendix -1) and indirect tax (for more, please see the Appendix-2). The rest of the revenue is collected from different non-tax sources. In between tax revenue the share of direct tax secured 31.83 percent and indirect tax covered the rest of 68.17 percent, Bangladesh Economic Review (2018) [1]. According to the data of National Board of Revenue (NBR) the share of indirect tax varies in between 65 to 70 percent for last ten years. The key instruments of indirect tax are Import Duty, Value Added Tax (VAT) (at import level), Supplementary Duty (import level), Export Duty, Excise Duty VAT (Local), Supplementary Duty (Local) and Turn Over Tax. The analysis of revenue collection for FY2017-18 by categories shows that income tax generates most revenues as a single category. However, indirect taxes including import duty and VAT are the largest in the overall revenue collection record.

Long run association between tax and economic growth is vital for the sound implementation of the policies as well as for ensuring social justice and equity. The Government of Bangladesh adopted a vision to be a middle income country by the year 2021. It has also adopted one more vision to become a developed country and the $26^{\text {th }}$ economy of the world by the year 2050. Under a Perspective Plan (20102021) [2] the government has taken up some specific targets which incorporate issues such as achieving enhanced standard of living, better standard of education, improved quality of social justice, improved socio economic environment and sustainable development. In order to attain all these, the government needs higher economic growth and for the higher economic growth it needs to improve the overall state of the infrastructure. To meet these targets GDP growth plays a vigorous role in the economy [3].

The aim of fiscal policy is to extent revenue range through strengthening revenue earning activities and expenditure management. These are defined according to the ability of the end taxpayer to shift the burden of taxes to someone else. The revenue collection of Bangladesh is primarily based on direct tax and indirect tax. The government has envisioned a middle income Bangladesh by 2021 through poverty alleviation and socioeconomic development of the people. The government is trying to ensure macroeconomic stability and conducive environment for sustained higher level of growth, Bangladesh Economic Review (2018). To achieve the goals the Government of Bangladesh has almost indiscriminately raised all kinds of tax and VAT without pondering the consequences. In addition to that, the government is also borrowing money from internal and external sources which would push the future tax burden to a new height. Imposing such a high rate of tax may result in harming the economy; that would eventually call in negative externalities (for more, please see the Appendix -3). According to the Economic Studies of Brookings, high rate of tax reduces domestic consumption, savings, investments, and ultimately affects the GDP [4]. A high rate of taxation could generate positive externalities only if the canons of taxation (for more, please see the Appendix -4) go in accord with the basis of such taxes. Generally, the canon of taxes tries to observe the objective of economic justice. It imposes that in absolute terms the richer should pay more taxes because without the protection of the government they could not have earned and enjoyed that extra income. The principles of canons of taxation have both an ethical aspect and administrative aspect to maintain the equity and justice to a particular state.

In Bangladesh the extreme poverty rate (Lower poverty line) has dropped to 12.9 percent from 17.6 and poverty rate (Upper poverty line) has dropped to 23.2 percent from 31.5 in between 2010 to 2016 [5] yet most of the people are living in the lower middle class strata and are often struggling to meet their basic needs. Therefore, to ensure social justice and welfare for the people at the field level the government should adopt an indirect tax policy based on the canons of equity to generate positive externalities. The consumption theory (Absolute Income Hypothesis) conveys that, GDP, Gross Domestic Savings (GDS) and Total Tax Revenue (TTR) are interrelated [6]. If the GDS increases then the GDP will increase but if the TTR increases then the GDS will fall. It ultimately means that the total investment will fall if the GDP falls. Figure 1 illustrates this relationship among GDP, GDS and TTR. Since the 1980s, all three of them are showing increasingly upward linear trend in Bangladesh while maintaining close link with each other.

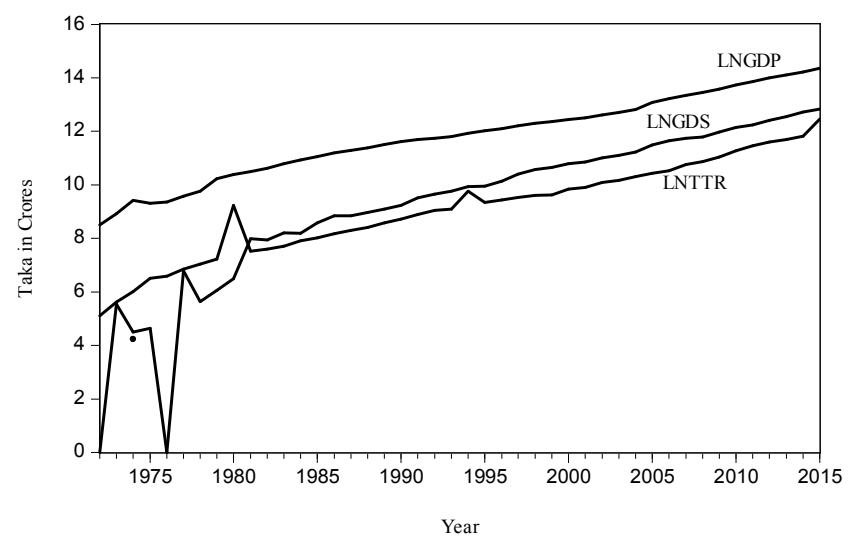

Source: National Board of Revenue (NBR)

Figure 1. Relationship of GDP, TTR and GDS. 
The year 1972 and 1976 observed fluctuation between the GDP and GDS in a biblical scale. In 1971, the year of independence, The taxation (TTR) had never faced a descending curve trend. The GDP from 1972 to 1979 was relatively low; as a result, the GDS was also very low between 1976 and 1982. In 1980 the government had amassed a vast amount of tax. After 1980, the GDS increase rate was more than that of the TTR and it had witnessed almost a parallel rate of increase with GDP. Therefore, by this analysis we could say that the GDS have extensive impact on the GDP; more than that of the TTR, because the GDS increased the GDP by raising the overall investment rate. However, the government never spends all that amount of TTR in the productive sector [7].

Supplementary duty is the major portion of indirect tax. The Government of Bangladesh has increased supplementary duty at local and import levels by raising TTR. In 2015, supplementary duty of Tk. 19630.96 cores was collected at the local level while the import level collection was Tk. 6560.2 cores. The supplementary duty collection at local levels was three times more than the import level. This type of duty collection is detrimental for domestic economy because at a time like this the imported goods become cheaper than the domestic products. The VAT also creates same kind of disincentive as it upsurges product's price. Figure 2 shows the trends of VAT at local and import levels between 1991 and 2015. Both trends were ascending. Up until 2005 the VAT collection at import level was more than that of the local level, which was worthy for the domestic investors and for the overall economy because it functioned as an incentive.

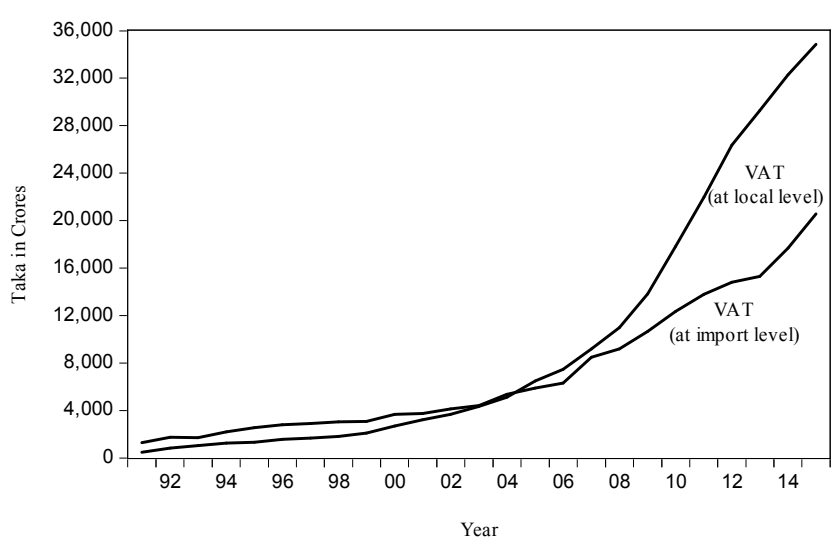

Source: National Board of Revenue (NBR)

Figure 2. Trends of VAT at local and import level.

The VAT collection at both local and import level went up after 2005. Between 2005 and 2015, government VAT collection at the local level was more than that of the import level. This is indicative of the fact that the government was immensely dependent on local level for its VAT collection.

\section{Review of Literature}

Tax is the principal source of government revenue.
According to the socioeconomic structure, producer and consumer are the determining forces to estimate the exact relationship between GDP growth and indirect taxation. The government has finally ensured producer's incentives and consumer's entitlement and these activities of government have been driven by taxation policy of the country. According to the study conducted by Nadeem Iqbal et al. (2015) [8], there is a negative relationship between growth of GDP and indirect tax. In addition to that, their studies were applicable in the case of value added tax. Using time series data examined the empirical analysis of tax revenues and its impact on economic growth of Pakistan starting from 1979 to 2010. They exhibited that there was significant positive impact of taxation on economic growth of Pakistan; i.e. if increase in sales tax and excise duties on all goods and services increase by one percent that, would lower the GDP growth of 3.8 percent targeted at 4.1 percent. The outcome of Plosser (1992) [9] presented that, if government increases 0.05 percent of the average tax rate, the economic growth rate would be reduced by 0.4 percent. To know the result, he has compared the growth rate of per capita GDP in 24 OECD countries from 1960 to 1989 and ended up with the correlation coefficient of -0.52 . Marginal tax rate plays a significant role in analyzing the long run impact on GDP growth rate through taxation. James et al. (2006) [10] have indicated that high marginal tax rates, particularly rates at 50 percent or more, exert an adverse impact on long-term economic growth. They estimated that a 10 percentage point reduction in a country's top marginal tax rate will enhance the country's long-term annual growth rate of real GDP by approximately three-tenths of a percentage point.

Another significant study from Canadian Economic Perspective demonstrates the impact of tax rate on economic growth. Ergete and Bev (2012) [11] examined the impact of the Canadian provincial governments' tax rates on economic growth using panel data covering the period between 1977 and 2006 and found that a higher provincial statutory corporate income tax rate is associated with lower private investment and slower economic growth. Their estimates suggest that a 1-percentage point cut in the corporate tax rate is related to a $0.1-0.2$ percentage point increase in the annual growth rate.

Engen and Skinner (1996) [12] have reexamined the relationship between economic growth and taxation in light of the accumulated economic evidence. They also found that it is not necessarily obvious that high taxes are bad for economic growth, either in theory or in the data. However, the evidence is consistent with lower taxes having modest positive effects on economic growth. The impact of tax found out differently in the various income groups in the society and finally it has become a useful explanatory variable to determine economic growth. Kalecki (1976) [13] argued that taxation on lower income groups reduced real wages leading to less savings and hence investments. While for the higher income groups, increased taxes decreased the level of consumption; with the overall effect of reducing economic growth. To achieve a target economic growth the 
reformation of tax policy plays a significant role:

Blanchard and Perotti (2002) [14], claim that both increases in taxes and increases in government expenditures affect investment spending negatively. Accordingly, tax reforms through raising individual and corporate taxes do not necessarily spell out economic growth through increased government revenue but they could also derail economic growth through reduced social welfare and poor investment incentives. Taxes levied to the public and business entities must be reasonable and an effective tax reform strategy should not aim at increasing the citizens' tax burden. Instead, reforms should focus on streamlining the system and ensuring that tax proceeds are used effectively to achieve economic growth.

The study of Chinese economy regarding tax revenue and GDP of Hebei Province has reviewed by Yi and Suyono (2014) [15]. The results of the study show that the negative impact of increase of tax revenue on economic growth may not be as serious as one might think and tax cuts would create more positive effects in Hebei Province. John et al. (2014) [16] examines the dynamic causal relationship between tax revenue components and economic growth in Nigeria. They used time series data on different types of taxes and GDP from 1986 to 2012. They found that total tax revenue has a significant effect on economic growth and that there exist a long-run equilibrating relationship between aggregate tax revenue and economic growth. Lutfunnahar (2007) [17] identified the determinants of tax share and revenue performance for Bangladesh along with 10 other developing countries for 15 years through a panel data analysis. The results suggested international trade, external debt and higher population growth are significant determinants of tax efforts. The study concluded low tax to GDP ratio for Bangladesh and other economies by not utilizing their tax revenue at full capacity that results in budgetary imbalance through raising tax revenue.

It is not a one to one simple relationship between tax rate and GDP growth. A reciprocal relationship is also given by Roshaiza et al. (2011) [18]. They analyze the relationship of economic growth and taxation revenue. This study included the annual data of Malaysia between 1970 and 2009. They used the GDP as standard of measurement of economic growth and concluded with the result that changes in taxes have no effect on economic growth. Another views found from neo-classical growth model of Solow. According to Solow (1956) [19] in his model implied that taxes do not affect the steady state of growth. In other words, tax policy though distortion, has no impact on long-term economic growth rates and total factor productivity.

\section{Rational of the Study}

Tax is a significant part of any country's fiscal policy regardless of its position in the development ladder. Although, by nature, Bangladesh's economy is rather vulnerable but it has been maintaining 6 to 7 percentage growth for last 12 years. As a powerful economic indicator the taxation policy influences Bangladesh's economy through consumption, saving and investment. The tax-based revenue influences economic growth negatively if the revenue budget solely depends on it. Therefore, this study aims to calculate the negative impact of indirect tax revenue on economic growth and tries to find a way out of those while time devises positive changes in the taxation policy through the canon of taxation to attain economic stability. The issue of tax policy and its impact on GDP growth rate is a delicate matter. It is very difficult to address and recommend proper policies of taxes without the long run study between indirect tax rate and growth rate. To attain the sustainable GDP growth rate those relationships need to be figured out.

\section{Objective of the Study}

The main objective of this study is to calculate the impact of indirect tax revenue on GDP to show the actual impact of taxation on economic growth of Bangladesh. It has the following objectives too.

1. To analyze the long-run relationship between the growth of GDP and indirect tax rate with the potentials of cointegration.

2. To know the causal relationship between the growth rate of GDP and indirect tax.

3. To forecast the impact of taxation on economic growth for sustainable development.

\section{Research Methodology}

\subsection{Sources of Data}

This paper is based on secondary time series data for the period from 1972 to 2015; composed from Bangladesh Bureau of Statistics (BBS), National Board of Revenue (NBR) Ministry of Finance, and Ministry of Planning of the Government of Bangladesh. The time series data covered a period of 43 years.

This study is mainly based on empirical analysis. This analysis is arranged by some econometric tests - ADF and KPSS tests for stationary and unit root testing of a time series, Johansen's cointegration tests for investigate long-run relationship, VECM for testing short run association of cointregated series and Pairwise Granger Causality tests for pairwise causal relationship.

\subsection{Hypothesis}

The null hypothesis of the study is

Ho: There is a significant negative relationship exist between the growth rate of GDP rate and indirect tax rate.

\subsection{Econometric Model}

A country's economic growth and her fiscal policy (tax) are interdependent from each other. The stability and sustainable economic growth demands appropriate fiscal 
policy. So, an equation for time series has been constructed in order to find out the relationship between GDP or economic growths with respect to tax revenue (for more, please see the Appendix -5) collected through indirect taxes of Bangladesh;

$$
\begin{gathered}
Y_{t}=\alpha+\beta_{1} i d t_{t}+\varepsilon_{t} \\
t=1992,1993 \ldots \ldots \ldots \ldots \ldots .2014
\end{gathered}
$$

Where, gross domestic product $(Y)$, indirect tax (idt) and $t$ stand for the $t^{\text {th }}$ time periods, $\alpha$ is a deterministic constant factor and $\varepsilon_{t}$ is a mean zero covariance stationary process and if the estimated value of $\beta_{1}$ is stationary significant then GDP and tax revenue can forecast.

\section{Empirical Features}

In this section, the study investigates whether there is a long-run relationship between GDP and tax revenue or not. The unit root tests of time series data is an augment of the univariate time series of unit root tests. The univariate unit root tests not easily to except null hypothesis of time series in unit root approach. Now, Assuming the simple time series model for GDP $\left(Y_{t}\right)$ with autoregressive AR (1) process.

$$
Y_{t}=\phi Y_{t-1}+\varepsilon_{t}
$$

Where, $\mathrm{t}=1,2,3, \ldots \ldots, \mathrm{t}$ is the time dimension, $\varepsilon_{t}$ is a stationary error term.

Equation (4) can be expressed as;

$$
\Delta Y_{t}=\rho Y_{t-1}+\varepsilon_{t}
$$

Therefore, the null hypothesis time series is stationary around a deterministic trend (trend-stationary) and the alternative hypothesis is unit root.

\subsection{Augmented Dickey-Fuller (ADF) Test}

The ADF test (1981) for a unit autoregressive root tests the null hypothesis $H_{0}: \gamma=0$ against the alternative $H_{1}: \gamma<0$ in the following regression:

$$
\Delta Y_{t}=\alpha+\gamma Y_{t-1}+\sum_{j=1}^{\rho} \delta_{j} \Delta Y_{t-j}+\varepsilon_{t}
$$

Where $\Delta$ is the first difference operator and $\varepsilon_{t}$ is a white noise error term and $\rho$ is the number of lags in the dependent variable $Y_{t}$. In the hypothesis testing $H_{0}$ implies $Y_{t}$ has a stochastic trend, while $H_{1}$ implies $Y_{t}$ is stationary. If $Y_{t}$ is stationary around a deterministic linear time trend, then the trend ' $t$ ' i.e., the number of observation must be added as an explanatory variable. Alternatively equation (4) can be written as;

$$
\Delta Y_{t}=\alpha+\beta t+\gamma Y_{t-1}+\sum_{j=1}^{\rho} \delta_{j} \Delta Y_{t-j}+\varepsilon_{t}
$$

In the equation (5) $Y_{t}$ is a random walk with drift around the stochastic trend. Here $\beta$ is an unknown coefficient and the ADF statistic is the OLS t-statistic testing null hypothesis $\gamma=0$ or not. If, the series found that the null hypothesis $\gamma=0$ is rejected in the level then the data implies stationary and differentiation will not needed to take. If, series is found that the null hypothesis, $\gamma=0$, is accepted in the level then first differentiation should be taken and second differentiation also can be taken in order to make the series of data stationary.

\subsection{Kwiatkowski-Phillips-Schmidt-Shin (KPSS) Test}

The alternative test ADF introduced in 1992 by Kwiatkowski, Phillips, Schmidt and Shin called henceforth the KPSS [20] test, has a null of stationary of a series around either mean or a linear trend; and the alternative assumes that a series is non-stationary due to presence of a unit root. The procedure is a test of non-stationary against the null hypothesis of stationary in the model;

$$
\begin{aligned}
Y_{t} & =\alpha+\beta t+\gamma \sum_{i=1}^{t} Z_{i}+\varepsilon_{t} \\
& =\alpha+\beta t+\gamma Z_{t}+\varepsilon_{t}
\end{aligned}
$$

Where, $\varepsilon_{t}$ is a stationary series, $\beta$ is unknown coefficient and $Z_{i}$ is an independent and identically distributed random variable stationary series with zero and variance one (these are merely convenient normalizations because a nonzero mean would move to $\alpha$ and a nonunit variance is absorbed in $\gamma$ ). If $\gamma$ equal zero, then the process is stationary and trend stationary if $\gamma$ is nonzero then $Y_{t}$ is non-stationary.

The KPSS test of the null hypothesis $H_{0}: \gamma=0$, against the alternative $H_{0}: \gamma<1$ or $H_{0}: \gamma=1$. Under the null hypothesis $\alpha$ and $\beta$ can be estimated by OLS. Let $e_{t}$ denote the $t^{t h}$ OLS residual

$$
e_{t}=y_{t}-\alpha-b t
$$

and let the sequence of partial sums be,

$$
E_{t}=\sum_{i-1}^{t} e_{t}, \quad t=1, \ldots \ldots, T
$$


The KPSS statistic is;

$$
\mathrm{KPSS}=\frac{\sum_{t=1}^{T} E_{t}^{2}}{T^{2} \hat{\sigma}^{2}}
$$

Where,

$$
\hat{\sigma}^{2}=\frac{\sum_{t=1}^{T} e_{t}^{2}}{T}+2 \sum_{j=1}^{L}\left(1-\frac{j}{L+1}\right) r_{j} \text { and } r_{j}=\frac{\sum_{s=j+1}^{T} e_{s} e_{s}-j}{T}
$$

And the researcher chooses L. Under the normality of the disturbances, $\varepsilon_{t}$ the KPSS statistic is an LM statistic that the researcher derives at under the general condition. If, computed value is greater than critical value then the null hypothesis, $\gamma=0$, stationary is rejected at a given level of significance. If, the series found that the null hypothesis, $\gamma=0$ is accepted in, the level then the data implies stationary and differentiation will not needed to take. If, the null hypothesis, $\gamma=0$, is rejected in the level then first differentiation should be taken and second differentiation can be taken in order to make the series of data stationary.

\subsection{Johansen Cointegration Test}

The Johansen (1988) [21] maximum likelihood (ML) methods of cointegration test widely used to identify the long run relationship between the time series variables. The Johansen method relies on a vector auto regression (VAR) model. A VAR is a system regression model, which includes more than one dependent variable (multivariate vector autoregressive models. Every variable is regressed on a combination of its own lagged values and lagged values of other variables from the system. Here, the researcher considers the following $n$ dimensional vector autoregressive (VAR) model of order $k$.

$$
Y_{t}=\mu_{t}+\sum_{i=1}^{K} A_{i} Y_{t-1}+\varepsilon_{t}
$$

Where $Y_{t}$ is a $n \times 1$ vector of variables that are integrated of order one which commonly denoted $I(1)$ and $\varepsilon_{t}$ a $n \times 1$ vector and $\mu_{t}$ is an independently and identically distributed random variable. In the case of the stochastic process of $Y_{t}$. Johansen and Juselius (1990) [22] propose two different ratio tests of the significance of these canonical correlations and thereby the reduced rank of the $\Pi$ matrix: the trace test and maximum eigenvalue test, shown in equations (10) and (11) respectively.

$$
\Delta Y_{t}=\mu_{t}+\prod Y_{t-1}+\sum_{i=1}^{K-1} \Gamma_{i} \Delta Y_{t-i}+\varepsilon_{t}
$$

Where,

$$
\Pi=-\left(I-\sum_{i=1}^{K} A_{i}\right) \text { and } \Gamma_{t}=-\sum_{j=i=1}^{K} A_{j}
$$

and $\Delta=1-L$, where $L_{\text {is }}$ the lag operator; $I$ is the $n \times r$ matrix; $A$ and elements of $Y_{t}$ will be given by the rank of $\Pi$, denoted as $r, \lambda$ is an eigenvalue of estimated $\Pi$. In the Trace test, the null hypothesis that there are at most $r$ Cointegrating vectors is tested (Against a general alternative) by calculating the test statistic;

$$
\lambda_{\text {trace }}(r)=-T \sum_{i=r+1}^{n} \ln \left(1-\hat{\lambda}_{i}\right)
$$

In this case, each in $\hat{\lambda}_{i}$ will be equal to zero (since $\log$ $1=0$ ), and $\lambda_{\text {trace }}$ will be equal to zero. However, the farther the estimated eigenvalues are from zero, the more negative is each of the expressions and the larger the $\lambda$ trace statistic. In the maximum eigenvalue test, the null hypothesis of $r$ cointegrating vectors is tested against the alternative of $(r+1)$ cointegrating vectors by calculating the test Statistic.

$$
\lambda_{\max }(r, r+1)=-T \ln \left(1-\hat{\lambda}_{r+1}\right)
$$

Again, if the estimated eigenvalue, $\hat{\lambda}_{r+1}$, is close to zero $\lambda_{\text {max }}$, will be large, and the null hypothesis that the number of cointegrating vectors is $r$ will be rejected.

\subsection{Vector Error Correction Model (VECM)}

If in Johansen cointegration test detected cointreagation between the series that means there exist a long running equilibrating relationship between explained and explanatory variables. So, researcher applies VECM for testing short run association of cointregated series. The regression equations of VECM are as follows:

$$
\Delta Y_{t}=\alpha_{1}+p_{1} q_{1}+\sum_{i=0}^{n} \beta_{i} \Delta Y_{t-i}+\sum_{i=0}^{n} \delta_{i} \Delta T_{t-i}+\sum_{i=0}^{n} \gamma_{i} Z_{t-i}
$$




$$
\Delta T_{t}=\alpha_{2}+p_{2} q_{2}+\sum_{i=0}^{n} \beta_{i} \Delta Y_{t-i}+\sum_{i=0}^{n} \delta_{i} \Delta T_{t-i}+\sum_{i=0}^{n} \gamma_{i} Z_{t-i}
$$

Where $p q$ is the error correction component of the model that measures the speed at which prior deviations from equilibrium are corrected. VECM indicates that any short term fluctuations between explained and explanatory variable give rise to the stable long run relationship between the variables.

\subsection{Granger Causality Test}

Finally the Granger Causality test (1969) [23] is carried out for checking the casual relationship between two variables such as $T$ (representing tax revenue) and $Y$ (representing GDP or economic growth). It is a prediction based econometrical concept. To say one variable $T$ Granger causes another variable $Y$ is to say that, by using past values of both variables $T$ and $Y$, we can better predict future values of $Y$ than by using only past values of $Y$ that is, past observations of $T$ contain information useful for predicting $Y$, beyond what is available from past observations of $Y$ itself. Suppose $T$ and $Y$ from a bivariate time series given by the dynamic relationship.

$$
\begin{aligned}
& Y_{t}=\phi+\sum_{i=1}^{n} \alpha_{i} Y_{t-i}+\sum_{j=1}^{n} \beta_{j} T_{t-j}+\varepsilon_{1 t} \\
& T_{t}=\lambda+\sum_{i=1}^{n} \delta_{i} Y_{t-i}+\sum_{j=1}^{n} \omega_{j} T_{t-j}+\varepsilon_{2 t}
\end{aligned}
$$

Where, $\phi$ and $\lambda$ represent intercepts, $\varepsilon_{1 t}$ and $\varepsilon_{2 t}$ are the white noise disturbance terms which are assumed stationary. The $T$ will Granger Cause $Y$ if the calculated $\mathrm{F}$ statistics is significant at conventional level and similar will occur in case of $Y$ to $T$.

\section{Study Outcomes}

This Part has been arranged by unit root ADF test (1981) and KPSS test (1992), Johansen-Juseliuscointegration test (1990), Vector Error Correction Model (VECM), Granger Causality test (1969) andstability test.

Table 2. Unit Root Tests Results (Without Trend).

\begin{tabular}{lllll}
\hline Variable & Method & Level & First difference & Second difference \\
\hline LNGDP & ADF & -1.276746 & $-5.902586^{* * *}$ & $-9.283513^{* * *}$ \\
LNIDT & ADF & -1.738212 & $-10.26220^{* * *}$ & $-13.83611^{* * *}$ \\
\hline
\end{tabular}

Note: For determination of optimal lag lengths used Schwarz Information Criterion (SIC) with maximum lag length automatically selected by Eviews software 7. (***,** and $*$ show level of significance at $1 \%, 5 \%$ and $10 \%$, respectively).

Table 2, the time series data unit root test ADF provides empirical evidence that GDP and IDT are non-stationary at level but in first and second difference are stationary because at first and second difference the null hypothesis of unit root are rejected and accepted alternative hypothesis at $1 \%$ and $5 \%$ level of significance.

Table 3. Unit Root Tests Results (With Trend).

\begin{tabular}{lllll}
\hline Variable & Method & Level & First difference & Second difference \\
\hline LNGDP & ADF & -2.819584 & $-5.911985^{* * *}$ & $-9.353313^{* * *}$ \\
LNIDT & ADF & $-5.304905^{* * *}$ & $-10.26962^{* * *}$ & $-5.600671^{* * *}$ \\
\hline
\end{tabular}

Note: For determination of optimal lag lengths used Schwarz Information Criterion (SIC) with maximum lag length automatically selected by Eviews software 7. $(* * *, * *$ and $*$ show level of significance at $1 \%, 5 \%$ and $10 \%$, respectively).

Table 3, the time series data unit root test ADF provides empirical evidence that only GDP is non stationary at level but in first and second difference are stationary because at first and second difference the null hypothesis of unit root are rejected and accepted alternative hypothesis at $1 \%$ level

\begin{tabular}{|c|c|c|c|c|}
\hline Variable & Method & Level & First difference & Second difference \\
\hline LNGDP & KPSS & 0.839735 & $0.409266^{* *}$ & $0.295641^{*}$ \\
\hline LNIDT & KPSS & 0.844266 & $0.268574^{*}$ & $0.405086^{* *}$ \\
\hline
\end{tabular}
of significance.

Table 4. Stationary Tests results (Without Trend).

Note: For determination of bandwidth selection by Newey-West and BartleettKernel estimation automatically selected by Eviews software 7 . $(* * *, * *$ and * show level of significance at $1 \%, 5 \%$ and $10 \%$, respectively).

Table 4, the time series data stationary test KPSS provides empirical evidence that GDP and IDT are non stationary at level because the null hypothesis of stationary are rejected but in first and second difference are stationary because at first and second difference the null hypothesis of stationary are accepted and rejected the alternative hypothesis of non stationary at $5 \%$ and $10 \%$ level of significance. 
Table 5. Stationary Tests Results (With Trend).

\begin{tabular}{lllll}
\hline Variable & Method & Level & First difference & Second difference \\
\hline LNGDP & KPSS & $0.146582^{* * *}$ & $0.210163^{* * *}$ & $0.150848^{* * *}$ \\
LNIDT & KPSS & $0.134737^{* *}$ & $0.170408^{* * *}$ & 0.415520 \\
\hline
\end{tabular}

Note: For determination of bandwidth selection by Newey-West and BartleettKernel estimation automatically selected by Eviews software 7. (***, ** and * show level of significance at $1 \%, 5 \%$ and $10 \%$, respectively).

Table 5, the time series data stationary test KPSS provides empirical evidence that GDP and IDT are stationary at level because the null hypothesis of stationary are accepted at level and rejected the alternative hypothesis non stationary at $1 \%$ and $5 \%$ level of significance.

Table 6. Johansen Tests for Cointegration: 1972 - 2015.

\begin{tabular}{llllll}
\hline $\boldsymbol{H}_{0}$ & $\boldsymbol{H}_{1}$ & $\boldsymbol{\lambda}_{\text {trace }}$ & Prob. & $\boldsymbol{\lambda}_{\boldsymbol{m a x}}$ & Prob. \\
\hline$r=0$ & $r=1$ & $289.3395^{* * *}$ & 0.0001 & $33.87687^{* * *}$ & 0.0000 \\
$r \leq 1$ & $r=2$ & $163.2256^{* * *}$ & 0.0000 & $27.58434^{* * *}$ & 0.0000 \\
$r \leq 2$ & $r=3$ & $74.51326^{* * *}$ & 0.0000 & $21.13162^{* * *}$ & 0.0000 \\
$r \leq 3$ & $r=4$ & $32.05733^{* * *}$ & 0.0001 & $14.26460^{* * *}$ & 0.0001 \\
$r \leq 4$ & $r=5$ & 2.026251 & 0.1546 & 3.841466 & 0.1546 \\
\hline
\end{tabular}

Note: Here $r$ is number of cointegration vectors and lag intervals is 5. (*** and $* *$ show level of rejection at $1 \%$ and $5 \%$ respectively).

Table 6, The Johansen-Juselius (1990) maximum likelihood approach used to examine the long run relationship between the explained and explanatory variables. Here the cointegration of null hypothesis is $H_{0}$ and the alternative hypothesis is $H_{1}$. The $\mathrm{J}-\mathrm{J}$ cointregration test shows that the null hypothesis $r=0$ (none) to $r \leq 3$ (at most 3 ) are rejected because the $\lambda_{\text {trace }}$ and $\lambda_{\text {max }}$ statistic value are less than $5 \%$ level of significance respectively and accepted the alternative hypothesis $r=1, r=2, r=3$ and $r=4$ again the null hypothesis $r \leq 4$ (at most 4 ) is accepted because the $\lambda_{\text {trace }}$ and $\lambda_{\text {max }}$ statistic value are more than $5 \%$ level of significance respectively and rejected the alternative hypothesis $r=5$. These results provide the evidence that there are at least four cointegrating equation model. So, the evidence provides that there exist long running relationship between explained variable (GDP) and all other explanatory variables (DT, IDT, TTR and GDS).

Table 7. Vector Error Correction Tests for Short-Run Coefficients Estimates.

\begin{tabular}{lll}
\hline Variables & LNGDP & LNIDT \\
\hline Coefficients $\beta$ & -0.41429 & 1.199464 \\
Standard error & 0.06955 & 0.27448 \\
\hline
\end{tabular}

Note: $* * *$ and $* *$ show the level significance at $1 \%$ and $5 \%$ respectively. Standard errors in parentheses represent asymptotic p-values associated with the tests.

Table 7, the vector error correction tests results shows the coefficient of the model implies that percentage of error in the variables. In the GDP $41 \%$ error occurred for each year. Therefore, $41 \%$ error needs to be corrected each year then it will reach equilibrium after $2.43[(1 \div 41) \mathrm{X} 100]$ years and other variable as indirect tax already is in equilibrium.

Table 8. Johansen Normalized Cointegrating Tests for Long-Run Coefficients Estimates.

\begin{tabular}{lll}
\hline Variables & LNGDP & LNIDT \\
\hline Coefficients $\beta$ & 1 & $-0.963734 * *$ \\
Standard error & - & 0.02896 \\
\hline
\end{tabular}

Note: $* * *$ and $* *$ show significance at $1 \%$ and $5 \%$ respectively. Standard errors in parentheses represent asymptotic p-values associated with the tests.

From Table 8, the outcome of Johansen Normalized Cointegrating test of first cointegrating equation suggests that if revenue of indirect tax upsurge one percentage point then GDP will plummet 0.96 percent point.

Table 9. Pairwise Granger Causality Tests Result.

\begin{tabular}{lll}
\hline Null Hypothesis: & Obs & F-Statistic \\
\hline LNIDT does not Granger Cause LNGDP & 38 & $3.46411^{* * *}$ \\
LNGDP does not Granger Cause LNIDT & & 13.6094 \\
\hline
\end{tabular}

Note: $* * *$ and $* *$ show the level rejection at $1 \%$ and $5 \%$ respectively.

To know the significance of two variables, Table 9, the outcome of Pairwise Granger Causality tests showed that the independent relationship among the existing variables one by one. There is no cause and effect of GDP on indirect tax because they are not statistically significant. However, indirect tax Granger cause on GDP at one percent level of significance respectively which connotes the revenue instrument of indirect tax has a significant impact on GDP.

\section{Recommendations and Conclusion}

Based on the results of the study, the Government of
Bangladesh should adopt the following recommendations immediately for ensuring sustainable GDP growth and economic development as well.

1. To maintain social justice, fairness and equity; the revenue dependency on the instruments of indirect tax alteration to direct tax, that is, increase the share of direct taxation. The process of transformation should be worked under a particular plan rather than quick application.

2. The government is supposed to increase taxation area and tax base for their fiscal requirements, which finally will ensure the prevailing and upcoming development targets.

3. Tax policy and revenue collection procedure of the 
government have to be rationalized and reform with the context of social need. The objectives of the tax reform policy follows the basic rules of equity and social justice of Bangladesh.

This paper empirically analyzes the long run relationship between GDP growth and indirect tax for forecasting sustainable economic growth through social equity and justice of Bangladesh. For analyzing the long-term relationship, the paper uses time series data for the period between 1972 to 2015 . For the unit root test used ADF test (1981) and KPSS test (1992), for long run cointegration test among the variables used the Johansen-Juselius cointegration test (1990), VECM used for short run relationship between variables, Granger Causality test (1969) used for pairwise Granger cost test among the explained and for other explanatory variable finally used stability tests to examine whether the model is stable or not. The result implies that growth of GDP and indirect tax are having long run negative relationship, which also shows that indirect tax has significant negative impacts on GDP. The study result of Johansen Normalized cointegrating test presented that from the first cointegrating equation implies that if indirect tax raise 1percent then GDP will fall 0.96 percent. The economy will lose USD 2,572 million while collecting indirect taxes (for more, please see the Appendix -6) of USD 167.511. That is, the opportunity cost of the revenue earnings through indirect tax will be immense, which is not justified by the economic point of view and it does not go in accord with the issues of social justice and equity. Again, the outcome of the study finds that indirect taxes Granger cause on GDP at 1\% level of significance which shows indirect tax has the impact on GDP. If government increases indirect taxation with conventional way and without any concern for internal and external economic agents then it leads to a reduced economic growth (GDP) in the future. Generally, the impact and incidence of indirect taxation are differently executed for individuals, institutions, and even government. Again, the tax authority of Bangladesh (NBR) itself does not identify which strata of the society are responsible for the final burden of the indirect taxation.

Fiscal policy is a critical issue for the policy maker of a nation. The tools of a fiscal policy always vary according to the economic strength of producers and consumers activities. A prudent and sensible fiscal policy plays a significant role in meeting the spending priorities for achieving targeted economic growth and upholding macroeconomic stability of a country. Taxes are not mere numbers and percentages that are changed around on urge to generate revenue, they pose philosophical, ideological, and goal oriented questions. Countries must increase the progressive nature of their tax codes for ensuring the equity and justice in the society. In Bangladesh, inequality is so severe that it is almost unbearable and the best way to create a fair tax burden is to have direct progressive taxes that would replace the burden on the wealthy as opposed to regressive indirect taxes. In addition to that, the poor, in our country, have been suffering from this burden for a long time. Furthermore, taxes should not be used as a means to manipulate human behavior; the sole purpose of taxation should be economic, it should not cross over into the personal jurisdiction. For long-run sustainable economic growth the country should review, reform and improve its tax policy and tax to GDP ratio on the basis of its socio-economic conditions with respect to equity and social justice. The burden of heavy direct tax negatively effects wage earning people, infant and small business firms. The imposition of indirect tax on marginalized people creates heavy burden and most of the time violates social justice. Therefore, the government needs to take tax reform policy considering both direct and indirect taxes on the basis of socio-economic condition and the canons of taxation. This paper attempts to evaluate the long run relationship between indirect tax and GDP for sustainable economic growth. In the future researchers could incorporate data that are more comprehensive and improve the result through evaluation methodology for a more perfect result.

\section{Appendix}

\section{Appendix 1: Direct Tax}

The direct taxes are combination of income tax and other taxes like corporate tax, taxes on kinds of land rents, holding taxes.

\section{Appendix 2: Indirect Tax}

The indirect taxes are combination of import duty, export duty, excise duty, supplementary duty (local and import level), VAT (local and import level), turnover taxes.

\section{Appendix 3: Externalities}

An externality is an economic term referring to a cost or benefit incurred or received by a third party. However, the third party has no control over the creation of that cost or benefit. An externality can be both positive or negative and can stem from either the production or consumption of a good or service. The meaning it can affect society as a whole (Will Kenton May 26, 2019). Negative externalities occur when production and/or consumption impose external costs on third parties outside of the market for which no appropriate compensation is paid. This causes social costs to exceed private costs. (https://www.investopedia.com/terms/e/externality.asp)

\section{Appendix 4: Canons of Taxation}

Adam Smith laid down four principles of taxation, which he called canons of taxation. His clear and simple statement of the four canons of taxation that underpins a good tax system remains relevant to this date. These are-canons of equity, certainty, convenience and economy.

Equity: This canon requires the burden of taxation to be distributed according to taxpayer's ability to pay as measured by the income earned under the protection of the state.

Certainty: This canon means that the taxpayer should know how much tax he has to pay, the time by when it must be paid and the manner in which the tax must be paid. 
Convenience: This canon means that taxes must be collected in a form and time convenient to the taxpayer.

Economy: Considering that every tax has a cost of collection, this canon requires the revenue collected to exceed the costs of collection.

(https://www.academia.edu/5750563/Direct_and_Indirect Taxes_and_Smith_s_Four_Canons_of_Taxation)

\section{Appendix 5: Economic Growths and Tax Revenue}

$$
Y_{t}=\alpha+\beta_{1} T_{t}+\varepsilon_{t} ; \mathrm{t}=1992,1993 \ldots \ldots \ldots \ldots 2014
$$

Where, tax revenue $(T)$ and $\mathrm{t}$ stand for the $t^{\text {th }}$ time periods, $\alpha$ is a deterministic constant factor and $\varepsilon_{t}$ is a mean zero covariance stationary process and if the estimated value of $\beta_{1}$ is stationary significant then GDP and tax revenue can be forecasted.

Rewrite the equation as:

$$
\begin{array}{r}
Y_{t}=\alpha+\beta_{1} d T+\beta_{2} i d T_{t}+\varepsilon_{t} \\
\ln Y_{t}=\alpha+\beta_{1} \ln d T_{t}+\beta_{2} \ln i d T_{t}+\varepsilon_{t}
\end{array}
$$

and

$$
\text { Where, } T_{t}=d T_{t}+i d T_{t}
$$

Here, tax revenue divided by direct tax $(d T)$ and indirect $\operatorname{tax}(i d T)$

\section{Appendix 6: Collecting Indirect Taxes (Estimation)}

Total indirect taxes Tk. 1,40,711.06 crore in 2017-18 and GDP at current price (in billion Tk.) 22,505 in 2017-18. 1 percent of IDT equals to Tk. 1,407.11 crore, which equals to Tk. 14,071.1 millions equals to USD 167.511 millions. Here, 0.96 percent of GDP equals to Tk. 216.048 billion $=$ Tk. 2,16,048 million $=$ USD 2,572 million (USD $1=$ Tk. 84), Source: Bangladesh Economic Review (2018).

\section{Acknowledgements}

I like to thank my fellow student, Md. Asad, Master of Advanced Studies in Economics, National University, Bangladesh for data inputs and analysis.

\section{References}

[1] Bangladesh Economic Review (2018). Finance Division, Ministry of Finance, Bangladesh.

[2] Perspective Plan of Bangladesh (2010-2021). General Economics Division Planning Commission Government of the People's Republic of Bangladesh April 2012. Towards Middle Income Economy, 2-3.

[3] Annual Report 2015-2016 (2016). Research and Statistics Section, National Board of Revenue, Ministry of Finance, Bangladesh.
[4] Gale G, William Samwick A (2014). Andrew Effects of Income Tax Changes on Economic Growth. Economic Studies at Brookings, Washington, DC 20036. https://www.brookings.edu/wpcontent/uploads/2016/06/09_Ef fects_Income_Tax_Changes_Economic_Growth_Gale_Samw ick.pdf

[5] Household Income and Expenditure Survey (HIES) (2016). Pleminary Report, Bangladesh Bureau of Statistics, Statistics and Information Division (SID), Ministry of planning, Bangladesh, 40-42. https://www.academia.edu/37874731/Preliminary_Report_on _Household_Income_and_Expenditure_Survey_2016_BANG LADESH BUREAU OF STATISTICS BBS STATISTICS AND_INFORMATICS_DIVISION_SID

[6] Keynes J M (1936). The General Theory of Employment, Interest and Money. London, Macmillan (reprinted 2007).

[7] Hosen A, Asad Md (2018). Reconciliation between Taxation and GDP Growth in Bangladesh: Issues and Arguments for Social Justice. International Journal of Research in Commerce, Economics \& Management, 8 (10): 2-3.

[8] Nadeem I, Muhammad F A, Suliman S (2015). Empirical Analysis of Tax Revenues and Its Impact on Economic Growth of Pakistan. Journal of Economics and Sustainable Development, $\quad 6 \quad$ (1): 110-118 https://pdfs.semanticscholar.org/fdc0/d05f20260d533f05e5af9 9892ced5082286c.pdf

[9] Plosser C I (1992). The Search for Growth Federal Reserve of Kansas City. Symposium Series Policies for Long-Run Economic Growth. Economic Researcher, 35 (2): 57-86.

[10] James D, Gwartney Robert A, Lawson (2006). The Impact of Tax Policy on Economic Growth: Income Distribution and Allocation of Taxes. Social Philosophy and Policy, 23 (2): 28 -52.

[11] Ergete F, Bev D (2012). The Impact of Tax Cuts on Economic Growth: Evidence from the Canadian Provinces. National Tax Journal, 65 (3): 563-594. https://www.ntanet.org/NTJ/65/3/ntjv65n03p563-94-impact-tax-cuts-economic.pdf

[12] Engen E, Skinner J (1996). Taxation and economic growth. National Tax Journal, 49 (4): 617-642.

[13] Kalecki M (1976). Essays on Developing Economies, Sussex, The Harvester Press Limited.

[14] Blanchard O, Perotti R (2002). An Empirical Characterization of the Dynamic Effects of Changes in Government Spending and Taxes on Output. Quarterly Journal of Economics, 117 (4): $1329-68$.

[15] Yi F, Suyono E (2014) The Relationship between Tax Revenue and Economic Growth of Hebei Province Based on The Tax Multiplier Effect. Global Economy and Finance Journal, 7 (2): 1-18.

[16] John U I, Ebieri J, Emmanuel A (2014). Assessment of the Long-Run Equilibrium Relationship between Tax Revenue and Economic Growth in Nigeria: 1986 to 2012. The SIJ Transactions on Industrial, Financial \& Business Management (IFBM), 2 (2).

[17] Lutfunnahar B (2007). A Panel Study on Tax Effort and Tax Buoyancy with Special Reference to Bangladesh. Working Paper 715, Policy Analysis Unit (PAU), Research Department, Bangladesh Bank. 
[18] Roshaiza T, Loganathan Nanthakumar, Sisira R N (2011). The Effect of Economic Growth on Taxation Revenue: The Case of a Newly Industrialized Country. International Review of Business Research Papers, 7 (1): 319-329.

[19] Solow R (1956). A Contribution to the Theory of Economic Growth. Quarterly Journal of Economics, 70: 65-94.

[20] Kwiatkowski, Phillips, Schmidt, Shin (KPSS) (1992). Testing the Null Hypothesis of Stationary against the Alternative of a Unit Root. Journal of Econometrics, 54: 159-178.
[21] Johansen S (1998). Statistical Analysis of Cointegrating Vectors. Journal of Economic Dynamics and Control, 12: 231-254.

[22] Johansen S, K Juselius (1990). Maximum Likelihood Estimation and Inference on Cointegration With Applications to the Demand for Money. Oxford Bulletin of Economics and Statistics, 52: 169-210.

[23] Granger C W J (1969). Investigating Causal Relations by Econometric Models and Cross-spectral Methods. Econometrica, 37 (3): 424-438. 